\title{
A Bibliometric Study of John Dunning's Contribution to International Business Research
}

\author{
Um Estudo Bibliométrico da Contribuição de Jobn Dunning na Pesquisa em \\ Negócios Internacionais
}

\section{Un Estudio Bibliométrico de la Contribución de Jobn Dunning a la Investigación en los Negocios Internacionales}

\section{Manuel Anibal Silva Portugal Vasconcelos Ferreira ${ }^{1}$ Cláudia Sofia Frias Pinto ${ }^{2}$ Fernando Antonio Ribeiro Serra ${ }^{3}$ João Carvalho Santos ${ }^{4}$}

Received on December 13, 2011 / Approved on March 05, 2013

Responsible Editor: Ivam Ricardo Peleias, Doctor

Evaluation Process: Double Blind Review

\begin{abstract}
This article offers a review of John Dunning's contribution to international business (IB) research, so as to assess the impact of Dunning and of the Eclectic paradigm on this discipline. The contribution of Dunning and of the Eclectic paradigm - usually referred to as OLI - are a core reference to current international business research, namely for studying location
\end{abstract}

decisions, foreign investment, entry modes and internationalization, and for the multinational enterprise theory. First, we review the conceptual foundations of Dunning's academic contribution. Second, methodologically, we carry out a bibliometric study of articles published in 14 respected academic business magazines over a period of 31 years, between 1980 and 2010. A sample of 697 published articles that refer

1. PhD in Business Management by the University of Utah, USA. Professor at Universidade Nove de Julho - UNINOVE and Director of the Center of Research in International Business \& Strategy - globADVANTAGE - [manuel.portugal@uninove. br]

2. Master in International Business by the Instituto Politécnico de Leiria, Portugal, and Master in Project Management by Universidade Nove de Julho - UNINOVE. [claudia.frias.pinto@gmail.com]

3. Doctor in Materials Engineering and in Metallurgy and Chemical Process Engineering by the Pontifícia Universidade Católica do Rio de Janeiro - PUC/RJ. Professor at Universidade Nove de Julho - UNINOVE. [fernandoars@uninove.br]

4 Doctor in Business Management by the Faculdade de Economia at the Universidade do Porto and Professor at the Instituto Politécnico de Leiria, Portugal. [joao.santos@ipleiria.pt]

Authors' address: Av. Francisco Matarazzo, 612, São Paulo - SP Cep. 05001-100 - Brazil 
to Dunning's work supports the analysis of citations and co-citations matrixes and of relevant themes, allowing us to verify the influence of Dunning's work on the international business and Management disciplines. This study allowed us to identify the network of connections between Dunning's Eclectic paradigm and a variety of international business theories, concepts and authors, as well as with the main subjects studied in the discipline. We observed the connections to the transaction costs theory, resource-based view, industrial organization and evolutionary theory. This study also contributes to scholars' better understanding of the development of the discipline and of the structure of knowledge within connections between theories and authors. Through their contributions, scholars such as John Dunning leave their imprint on the way in which disciplines and knowledge evolve. Dunning's work, in the Eclectic paradigm, systematized three conditions that guide the internationalization of companies - and is now a reference for entrepreneurial activities, scholars and research.

Keywords: John Dunning. OLI. Eclectic paradigm. Bibliometric study. International business.

\section{RESUMO}

Este artigo proporciona uma revisão da contribuição de John Dunning na pesquisa em negócios internacionais, para entender o impacto de sua obra e do paradigma Eclético na disciplina. A contribuição de Dunning e do paradigma Eclético - usualmente referido como OLI - é uma referência central na pesquisa atual em negócios internacionais e, mais frequentemente, para o estudo de decisôes de localização, investimento, modos de entrada e internacionalização e para a teoria da empresa multinacional. Primeiro, fazemos uma revisão dos fundamentos da contribuição acadêmica de Dunning. Segundo, metodologicamente, realizamos um estudo bibliométrico dos artigos publicados em 14 periódicos acadêmicos de alta reputação na área da Administração, em um período de 31 anos, entre 1980 e 2010 . Uma amostra de 697 artigos que citam o trabalho de Dunning apoia a análise de matrizes de citaçôes e co-citations e dos temas abordados, permitindo verificar a influência dos trabalhos de Dunning na disciplina de negócios internacionais e em Administração, em sentido mais amplo. Este estudo permitiu identificar a rede de ligações do paradigma Eclético de Dunning com uma variedade de teorias, conceitos e autores em negócios internacionais, além de com os principais temas estudados na disciplina. Observamos as ligaçôes com a teoria dos custos de transação, visão baseada nos recursos, organização industrial e teoria evolucionária. Contribui, também, para os acadêmicos compreenderem melhor o desenvolvimento da disciplina e a estrutura do conhecimento nas inter-relaçóes entre teorias e autores. Alguns autores, como John Dunning, marcam a forma como as disciplinas e o conhecimento evoluem com suas contribuições. O trabalho de Dunning, no paradigma Eclético, sistematizou três condições que presidem a internacionalização das empresas e é hoje uma referência para a prática empresarial, os acadêmicos e a pesquisa.

Palavras-chave: John Dunning. OLI. Paradigma eclético. Estudo bibliométrico. Negócios internacionais.

\section{RESUMEN}

Este artículo ofrece una revisión de la contribución de John Dunning a la investigación de los negocios internacionales, para comprender el impacto del trabajo de Dunning y del paradigma Ecléctico en la disciplina. La contribución de Dunning y del paradigma Ecléctico - normalmente denominado OLI - es una referencia central en la investigación actual de los negocios internacionales, en particular el estudio de las decisiones de localización, inversión, entrega e internacionalización, así como para la teoría de la empresa multinacional. 
En primer lugar, se revisaron los fundamentos de la contribución académica de Dunning. En segundo lugar, metodológicamente, se realizó un estudio bibliométrico de los artículos publicados en 14 revistas académicas de prestigio, en el área de Administración, en un período de 31 años, entre 1980 y 2010 . Una muestra de 697 artículos que mencionan a Dunning apoya el análisis de las matrices de citas y co-citas y los campos estudiados que permiten comprobar la influencia del trabajo de Dunning en la disciplina de los negocios internacionales y en la Administración en el sentido más amplio. Este estudio ha permitido identificar una red de conexiones del paradigma ecléctico de Dunning con una variedad de teorías, conceptos y autores de negocios internacionales, y con los principales temas estudiados en la disciplina. Observamos las conexiones con la teoría de los costes de transacción, visión basada en recursos, organización industrial y teoría evolucionaria. Ha contribuido igualmente a que los académicos comprendieran mejor el desarrollo de la disciplina y la estructura del conocimiento de las interrelaciones entre teorías y autores. Algunos autores, como John Dunning, marcan con su contribución la forma en que las disciplinas y el conocimiento evolucionan. El trabajo de Dunning, en el paradigma Ecléctico, ha sistematizado tres condiciones que encabezan la internacionalización de las empresas y es hoy una referencia para la práctica empresarial, los académicos y la investigación.

Palabras clave: John Dunning. OLI. Paradigma ecléctico. Estudio bibliométrico. Negocios internacionales.

\section{INTRODUCTION}

The current business scenario does not allow executives to ignore the many aspects of foreign markets, from commercialization to production. From car industries to cinema, from fast food to consumer electronics, globalization has widened the scope of company activities and executive minds. To keep up with these changes, research concerning international business has taken new paths, absorbed new concepts and approaches and begun to focus on increasingly relevant topics, such as the internationalization of small companies - the born global -, international entrepreneurship, the relationship between corporate headquarters and subsidiaries scattered around the world, and entry into emerging markets, amongst others. One of the most important changes - which, by the way, has followed the evolution of management as a discipline - is focus on companies' internal aspects - its strategic resources, capabilities and knowledge - in relative disadvantage of approaches based on simply external or transactional factors. However, even when changes in conceptual approaches do occur, certain earlier theories remain because of their usefulness, accuracy or impact on the way of thinking and researching.

This paper analyzes John Dunning's influence on academic research concerning international business and strategy. Dunning's proposed connection between the nature of multinational companies' international production and the factors that affect their location influences, directly or indirectly, most of the research carried out in international business/management. Dunning's research gained recognition by proposing a taxonomy of three key aspects to companies' internationalization and, specially, to their decision to produce abroad. This taxonomy, known as the Eclectic paradigm, or simply as OLI, includes three vectors: ownership, location and internalization. Dunning's proposed taxonomy of factors that sustain the decision to internationalize - based on company-specific advantages, on the choice of production location and between internalization or externalization of transactions - is the theoretical foundation of several surveys that, over the last three decades, have focused on multinational enterprises' (MNEs) 
operations. This is one of the most recognized theoretical models in international business (STOIAN; FILIPPAIOS, 2008), perhaps because it is an approach that combines the various factors that explain multinational enterprises' activities (HUGGINS; DEMIRBAG; RATCHEVA, 2007). The importance of Dunning's extensive work, carried out over fifty years of academic life, and of his contributions, is evident in current references to his earlier work (DUNNING, 1958, 1972, 1973, 1977) on the Eclectic paradigm and on the rationale of multinational enterprises and their investments abroad (DUNNING, 1981b, 2000). Peng and Zhou (2006) and Ferreira et al. (2011) considered Dunning one of the most important references in international strategy, and Lahiri and Kumar (2012) as the fourth most important author in the world's main international business journal, the Journal of International Business Studies, amongst authors such as Yadong Luo, Peter Buckley, and John and Klaus Meyer.

The purpose of this article is to examine the theoretical contribution of an author John Dunning - and of the Eclectic paradigm to the development of the discipline, and the author's influence, which presumably extends beyond its initial restricted domain in international business, with branches in research concerning business strategy and, more broadly, of Management. Thus, we analyzed articles published in 14 highly respected academic journals over a 31-year period, from 1980 to 2010 - Academy of Management Journal, Academy of Management Review, Asia Pacific Journal of Management, International Business Review, International Marketing Review, Journal of World Business, Journal of International Business Studies, Journal of International Management, Journal of Management, Journal of Management Studies, Management International Review, Organization Science, Organization Studies, and Strategic Management Journal. Bibliometric analysis of 675 articles published in these journals mentioning the work of Dunning allowed us to better understand the intellectual structure that connects authors and theories (WHITE; MCCAIN 1998; RAMOS-RODRIGUEZ, RUIZ-NAVARRO, 2004; FERREIRA et al., 2011). Our goal is to identify the essence of Dunning's contribution - the Eclectic paradigm - within international business research and to analyze connections with other authors and topics, through bibliometric analysis of citations and co-citations.

This paper is structured as follows: in the first part, we analyze the genesis of the Eclectic paradigm. Next, we present our methodology, data collection procedure and sample. Results are presented before a broad discussion that points out a few limitations and prospects for future research.

\section{THE ECLECTIC PARADIGM}

Dunning's academic career was focused on the development, and subsequent extensions, of the Eclectic paradigm (DUNNING, 1977, 1995, 2004). The Eclectic paradigm is an approach to international production, that is, to production carried out abroad by means of foreign direct investment (FDI) (see specially DUNNING, 1977, 1981b, 1988, 1993a, 2000). The paradigm explains the motives and reasons (why), the location (where) and the way (how) by which multinational companies' international operations are carried out. It's called Eclectic because it integrates different theoretical approaches, converting them into a single taxonomy, commonly referred to as the OLI. In essence, the Eclectic paradigm's conceptual goal is to explain why there are multinational enterprises (MNEs) and why they may be relatively more successful than domestic firms (HYMER, 1976, DUNNING, 1988; DUNNING; WYMBS, 2001).

Dunning's work can be traced to its origins, in 1958, with his doctoral thesis - 
American Investment in British Manufacturing Industry -, when he observed that companies operating in the US presented higher levels of productivity than their counterparts in England. As such, he suggested two types of factors that came to be known as ownership advantages and location advantages. Ownership advantages are those that the company owns, and that it could transfer to other operations, mainly abroad. They demonstrate a competitive advantage the MNE has in holding a specific resource, capability or asset, giving it a greater capacity to create value. Thus, ownership advantages may result from better technology, intangible assets, or to a more efficient production process and to better management capacity, amongst others.

Location advantages are explained as specific to certain locations (regions or countries), which cannot be appropriated at a distance and that benefit only companies located there. That is, to benefit from the location advantages, companies need to have operations on site. Thus, the MNE needs to take site-specific factors into account, such as cost of production factors, accessibility, availability of knowledge, government industrial policies, market size and potential, amongst others. The selected location for operations affects the company's capacity to exploit its specific assets or resources (ownership advantages). So, inherent to the analysis of location advantages is the fact that these resources are not marketable, so they cannot be transferred to another location (RUGMAN, 1981).

Dunning's studies concerning ownership and location advantages complement certain neoclassical theories of his time, especially those referring to allocation of factors (LEONTIEF, 1953; HYMER, 1976; POSNER, 1961). However, the Eclectic paradigm was very different when compared to prevailing theories, especially by considering that many of the factors were specific to companies and, as such, were mobile - to the extent that companies could move them, even though imperfectly (DUNNING, 1972;
HENNART, 1982; DUNNING; LUNDAN, 2008). In the 1960s, the prevailing economic vision dictated that assets would only be transferable if structural market imperfections (such as government intervention or monopolies) could be removed (DUNNING; RUGMAN, 1985). One of the elements that were different in Dunning was his emphasis not on structural restrictions of access to local factors (such as tariff barriers or restrictions to ownership), but on the imperfect transference of ownership advantages that prevented companies from transferring their specific competitive resources (or assets) abroad (RUGMAN, 1981).

The third component in the Eclectic paradigm - internalization advantages - emerged in an academic context in which the role of institutions (AKERLOF, 1970; WILLIAMSON, 1971; ALCHIAN; DEMSETZ, 1972; SPENCE, 1976) and the internalization of activities were gaining relevance, given developments in transaction cost theory (BUCKLEY; CASSON, 1976; NORTH, 1984; TEECE, 1981, 1986; NELSON; WINTER, 1982; WILLIAMSON, $1975,1985)$. Thus, the Eclectic paradigm became complete, made up of three factors: ownership, location and internalization (DUNNING, 1981b).

Internalization advantages - or the choice between operation internalization or externalization - are companies' benefits that result from exploiting their ownership advantages internally, rather than through market transactions. That is, why do companies choose to market their specific advantages rather than exploit them internally? The existence of multinational companies themselves can only be explained given internalization advantages. Guisinger (2001) proposes to change the I, in OLI, to $\mathrm{M}$, which means input modes - given that the option to internalize reflects on the selection of modes of entry into foreign markets. In certain cases, the benefits of carrying out operations internally are greater, especially to exploit specific 
features more effectively - and, in these cases, the MNE carries out FDI. In other cases, efficient market hiring or licensing to external partners are possible. As a general rule, the more important the exploitation of ownership advantages in a given foreign country, the greater the tendency towards internalization of operations through FDI.

The three advantages - ownership, location and internalization, which make up the OLI have to be present simultaneously for MNEs to prefer carrying out IDE rather than alternative entry modes (DUNNING, 1977, 1981a, 1981b, $1988,1995,2001)$. The combination of these three advantages can explain the scope and geographical distribution of MNEs's activities (see, for example, DUNNING, 1993a).

In short, according to Dunning (1988), the way in which MNEs behave depends on a combination of three factors. Table 1 gives examples of these kinds of advantages.

Table 1 - OLI advantages.

\begin{tabular}{|c|c|c|}
\hline Ownership or firm-specific advantages & Location advantages & Internalization advantages \\
\hline Access to markets, products and factors. & Market potential. & Reduction in transaction costs. \\
\hline Product differentiation. & Input price differences. & Property rights protection. \\
\hline \multirow{2}{*}{$\begin{array}{l}\text { Risk diversification. } \\
\text { Specific appropriations: staff, capital, } \\
\text { organization. }\end{array}$} & $\begin{array}{l}\text { Quality of inputs (natural resources, } \\
\text { skilled labor). }\end{array}$ & \multirow{2}{*}{$\begin{array}{l}\text { Solution of asymmetrical information } \\
\text { problems between suppliers and } \\
\text { customers (market imperfections). }\end{array}$} \\
\hline & Financial resources. & \\
\hline \multirow{2}{*}{$\begin{array}{l}\text { Greater efficiency, coordination and } \\
\text { leverage of resources from different } \\
\text { locations, improving company capacities. }\end{array}$} & \multirow{2}{*}{$\begin{array}{l}\text { Transportation, communications and } \\
\text { infrastructure costs. }\end{array}$} & Reduction in exchange costs. \\
\hline & & Possibility of agreements. \\
\hline $\begin{array}{l}\text { Use of parent company's resources } \\
\text { (through transfer pricing, for example). }\end{array}$ & $\begin{array}{l}\text { Free trade barriers (import quotas, } \\
\text { tariffs) }\end{array}$ & $\begin{array}{l}\text { Ways of avoiding or exploiting state } \\
\text { interventions (such as customs tariffs } \\
\text { or investment incentives). }\end{array}$ \\
\hline $\begin{array}{l}\text { Greater dimension, scale economies and } \\
\text { scope. }\end{array}$ & Investment policies; country risk. & $\begin{array}{l}\text { Reduction in buyers' and/or sellers' } \\
\text { uncertainty. }\end{array}$ \\
\hline International experience. & Country's tax breaks. & Offer control in quantity and quality. \\
\hline \multirow{3}{*}{$\begin{array}{l}\text { Flexibility in acquisition and production, } \\
\text { for better location. } \\
\text { Recognition of fusion and acquisition } \\
\text { opportunities. }\end{array}$} & Physical distance, language, culture. & Sales control. \\
\hline & \multirow[t]{2}{*}{$\begin{array}{l}\text { Clusters of related companies, } \\
\text { taking advantage of agglomeration } \\
\text { externalities. }\end{array}$} & $\begin{array}{l}\text { Strategic gains. } \\
\text { Internalization of positive externalities. }\end{array}$ \\
\hline & & Inexistence of forward markets. \\
\hline
\end{tabular}

Source: Adapted from Dunning (1999b).

Over the last three decades, the Eclectic paradigm has faced various developments and extensions (Table 2) and, following the publishing, in 1995, of The Eclectic Paradigm in an Age of Alliance Capitalism, Dunning revealed how focus moves from issues concerning only
FDI and international production to including the very structure of the multinational company, increasingly considered a network (HEDLUND, 1986; BARTLETT; GHOSHAL, 1989; LI; FERREIRA; SERRA, 2009). 
Table 2 - Genealogy of the OLI paradigm.

\begin{tabular}{|c|c|c|}
\hline Year & Article/book title & Contribution \\
\hline 1958 & $\begin{array}{l}\text { DUNNING, J. (1958) American Investment in } \\
\text { British Manufacturing Industry. }\end{array}$ & $\begin{array}{l}\mathrm{O} \text { and L components are identified in direct North-American } \\
\text { investments in the English industry. }\end{array}$ \\
\hline $\begin{array}{l}1972 \mathrm{e} \\
1973\end{array}$ & $\begin{array}{l}\text { DUNNING, J. (1972) The Location of } \\
\text { International Firms in an Enlarged EEC. An } \\
\text { Exploratory Paper. } \\
\text { DUNNING, J. (1973) The Determinants of } \\
\text { International Production. }\end{array}$ & $\begin{array}{l}\mathrm{O} \text { and } \mathrm{L} \text { components are employed to explain the probable } \\
\text { consequences that result from England joining the European } \\
\text { Common Market. }\end{array}$ \\
\hline 1977 & $\begin{array}{l}\text { DUNNING, J. (1977) Trade, Location of } \\
\text { Economic Activity and the MNE: A Search for } \\
\text { an Eclectic Approach. }\end{array}$ & $\begin{array}{l}\text { Presents international production eclectic theory and reasons } \\
\text { for this designation. Component } \mathrm{I} \text { is added. }\end{array}$ \\
\hline 1981 & $\begin{array}{l}\text { DUNNING, J. (1981a) Explaining the } \\
\text { International Direct Investment Position of } \\
\text { Countries: Towards a Dynamic or Developmental } \\
\text { Approach. }\end{array}$ & $\begin{array}{l}\text { Applies eclectic theory to explaining changes in } \\
\text { stance along four phases of economic developr }\end{array}$ \\
\hline 1981 & $\begin{array}{l}\text { DUNNING, J. (1981b) International } \\
\text { Production and the Multinational Enterprise. }\end{array}$ & $\begin{array}{l}\text { Changes terminology. Eclectic theory becomes Eclectic } \\
\text { paradigm. Explains change. }\end{array}$ \\
\hline 1988 & $\begin{array}{l}\text { DUNNING, J. (1988) The Eclectic Paradigm } \\
\text { of International Production: A Restatement and } \\
\text { Some Possible Extensions. }\end{array}$ & $\begin{array}{l}\text { Divides ownership advantages into two types: asset-based } \\
(\mathrm{Oa}) \text { and transaction-based (Ot). Gives various suggestions } \\
\text { for research applying the Eclectic paradigm - for example: } \\
\text { foreign disinvestment, FDI effects, dynamics involving FDI, } \\
\text { formalization of the paradigm etc. }\end{array}$ \\
\hline 1993 & $\begin{array}{l}\text { DUNNING, J. (1993a) Multinational } \\
\text { Enterprises and the Global Economy. }\end{array}$ & $\begin{array}{l}\text { Presents a new version of the Eclectic paradigm, which now } \\
\text { encompasses FDI for improving resources (parallel to FDI } \\
\text { focused on exploiting resources that are already available). }\end{array}$ \\
\hline 1993 & $\begin{array}{l}\text { DUNNING, J. (1993b) The Globalization of } \\
\text { Business. }\end{array}$ & $\begin{array}{l}\text { Recognizes the importance of strategy as a company's } \\
\text { dynamic and specific variable, capable of influencing the } \\
\text { OLI configuration faced by companies, also analyzing their } \\
\text { reactions facing the new configuration. }\end{array}$ \\
\hline 1995 & $\begin{array}{l}\text { DUNNING, J. (1995) Reappraising the Eclectic } \\
\text { Paradigm in the Age of Alliance Capitalism. }\end{array}$ & $\begin{array}{l}\text { The paradigm now includes advantages that emerge } \\
\text { from value-added operations and from relationships with } \\
\text { institutions and/or resources in foreign countries. That is, it } \\
\text { encompasses phenomena that is characteristic of a time of } \\
\text { alliances between companies. }\end{array}$ \\
\hline 1996 & $\begin{array}{l}\text { DUNNING, J. \& NARULA. R. (Orgs.) (1996) } \\
\text { Foreign Direct Investment and Governments. }\end{array}$ & $\begin{array}{l}\text { Considers theory on internationalization as a gradual process } \\
\text { (investment development path) and adds a fifth phase of } \\
\text { development to encompass FDI seeking resources (asset } \\
\text { seeking). }\end{array}$ \\
\hline $1998 / 9$ & $\begin{array}{l}\text { DUNNING, J. (1998) Location and the } \\
\text { Multinational Enterprise: A Neglected Factor. } \\
\text { DUNNING, J. (1999a) Globalization and } \\
\text { theTtheory of MNE Activity. }\end{array}$ & $\begin{array}{l}\text { Analyzes how technological development and globalization } \\
\text { determine the content and configuration of OLI advantages. } \\
\text { Explains intra triad investment of resource seeking type } \\
\text { investments. }\end{array}$ \\
\hline 1999 & $\begin{array}{l}\text { DUNNING, J. \& DILYARD, J. (1999) } \\
\text { Towards a General Paradigm of Foreign Direct } \\
\text { and Foreign Portfolio Investment. }\end{array}$ & $\begin{array}{l}\text { Expansion of the OLI paradigm, now including foreign } \\
\text { portfolio investment components (as such, shorter term } \\
\text { investments). }\end{array}$ \\
\hline 2000 & $\begin{array}{l}\text { DUNNING, J. (2000) The Eclectic Paradigm as } \\
\text { an Envelope for Economic and Business Theories } \\
\text { of MNE Activity. }\end{array}$ & $\begin{array}{l}\text { Paradigm is presented as an MNE envelope theory bringing } \\
\text { together complementary theories and concepts } \\
\text { based on economy, and on organizational and management } \\
\text { theory. Presents new challenges to the Ecletic paradigm. }\end{array}$ \\
\hline
\end{tabular}

Source: Adapted from Dunning (1999b). 
Dunning (1988, 1993b) proposes four different types of reasons for carrying out foreign investment, as follows.

- resource seeking - seeks access to natural resources, raw materials or other productive factors in more advantageous conditions (for example, in greater abundance and at a lower cost).

- market seeking - seeks entry into a new market so as to, for example, expand the customer base.

- efficiency seeking - aims at improving the efficiency of the MNE, making it more productive, for example, through better division of labor or specialization of its resources.

- $\quad$ strategic asset seeking - aims at developing company skills, resources and capabilities, helping to increase its competitive advantage. Motivation behind strategic resource seeking by MNEs has gained relevance (KOGUT; ZANDER, 1992, 1993), indicating that the location factor loses significance in favor of ownership and internalization advantages as a requirement for $\mathrm{MNE}$ operations.

In subsequent extensions of work on the Eclectic paradigm, Dunning $(1995,1997)$ refers to forms of cooperation between companies, such as strategic alliances, to observe how the OLI trilogy can be changed, affecting the performance of FDI. Collaboration models between companies help reduce market imperfections, at least in certain situations, thus reducing the need to internalize operations to capture ownership advantages of valuable resources.

One of the key contributions of Dunning's work (already evident in 1988) was the establishment of a requirement: that companies present a specific competitive advantage as a precondition to the very existence of multinational companies. Indeed, a great deal of the focus of research on international business, nowadays, is based on what these features are, and on how they influence MNEs in multiple dimensions - from choosing locations to entry modes and the configuration of relationships between subsidiaries abroad (BARTLETT; GHOSHAL, 1989; KOGUT; CHANG, 1991; KOGUT; ZANDER, 1992, 1993; LI; FERREIRA; SERRA, 2009). Currently, this line of research is supported by the resource-based view developed by authors such as Barney (1986, 1991), Wernerfelt (1984), Penrose (1959), Tallman (1991) and Peteraf (1993) , amongst others. In fact, current focus given to a specific resource is not irrelevant: knowledge, as the originator of MNEs (KOGUT; ZANDER, 1992).

\section{BIBLIOMETRIC STUDY}

\section{I Method}

The bibliometric method employed is based on the one described by Ramos-Rodriguez and Ruiz-Navarro (2004) when analyzing the evolution and changes in the intellectual structure of the research, published in the Strategic Management Journal. In this bibliometric research, we examine articles that were published seeking to identify relationships between authors and topics within research. Specifically, we use citation and co-citations analysis (BROWN, GRIFFITH, 1981; WHITE; MCCAIN, 1998). Citation analysis depends on the use of other documents (books, articles, etc.) that authors refer to when writing their academic papers.

The use of these references reveals that certain previous work is important to their own work, or serves as a reference to it. It is therefore reasonable to suggest that the more an article is mentioned, and by the most authors, the greater its influence to the discipline and the development of knowledge (TAHAI; MEYER, 1999). Analysis of co-citations, in turn, examines possible groups or pairs of articles that are mentioned simultaneously in the same article. Thus, articles that are mentioned together within the same article are likely to share some content, or serve the same purpose. Through this process, we are able to establish groups of authors, topics and theories to understand how they might be related (see, in this respect, WHITE, GRIFFITH, 1981; MCCAIN 1990; WHITE; MCCAIN, 1998). 


\subsection{Sample}

The bibliometric study carried out focused on 14 respected Management journals. Journals and their ratings (Table 3) were selected from Ann-Will Harzing's work (2011) Journal Quality List (available on <www.harzing.com/jql.htm>). Several studies used an identical or narrower selection of journals, but also included the ones used here (WERNER, 2002; LU, 2003; PENG; ZHOU, 2006; FERREIRA et al., 2009; PISANI, 2009; TREVINO et al., 2010; FERREIRA et al., 2011; LAHIRI; KUMAR, 2012). These journals are among the highest ranked for publishing scientific articles on international business: Journal of International Business Studies (JIBS), Management International Review (MIR), International Business Review (IBR), Journal of World Business (JWB) and Journal of International Management (JIM). Other journals that publish research on international business, although more general in their Management vocation, were also included: Academy of Management Journal (AMJ), Academy of Management Review (AMR), Journal of Management (JM), Asia Pacific Journal of Management (APJM), Journal of Management Studies (JMS), Organization Science (OS), Organization Studies (Ost) and Strategic Management Journal (SMJ).

These 14 journals are available for download on online databases which universities usually subscribe, although facing eventual time restrictions. All journals are also available on the ISI Web of Knowledge, from where data used in this research was taken. Generically, the 1980-2010 period was considered - 31 years - for analysis. Please note that some journals do not present data for the entire period, as shown by Table 3 . For example, $J W B$ is only available from 1997 to 2011, and APJM, from 1998 to 2011, but other journals have a long available history, such as JIBS, whose entries begin in 1976, and $A M J$, beginning in 1958, making analysis of the whole considered period possible.

Table 3 - Ranking of journals on which research was based.

\begin{tabular}{|c|c|c|c|c|c|c|c|c|c|}
\hline \multirow[b]{2}{*}{$\begin{array}{l}\text { Years } \\
\text { published }\end{array}$} & \multirow[b]{2}{*}{ Journal } & & \multicolumn{4}{|c|}{ Ranking (1) } & \multirow[b]{2}{*}{$\begin{array}{l}\text { Impact } \\
\text { factor } \\
(6)\end{array}$} & \multirow{2}{*}{$\begin{array}{c}\text { Total } \\
\text { number of } \\
\text { citations } \\
(7)\end{array}$} & \multirow[b]{2}{*}{$\begin{array}{c}\text { Number of } \\
\text { publications } \\
\text { (8) }\end{array}$} \\
\hline & & & $\begin{array}{c}\text { ABCD } \\
2010 \\
(2)\end{array}$ & $\begin{array}{c}\text { ABS } \\
2010 \\
(3) \\
\end{array}$ & $\begin{array}{c}\text { CRA } \\
2010 \\
(4)\end{array}$ & $\begin{array}{c}\text { ESS } \\
2010 \\
(5)\end{array}$ & & & \\
\hline $1976-2011$ & JIBS & Journal of International Business Studies & $\mathrm{A}^{*}$ & 4 & 4 & 0 & 4.184 & 40.120 & 1.761 \\
\hline $\begin{array}{l}1966- \\
2008 / 2008- \\
2011\end{array}$ & MIR & Management International Review & A & 4 & 4 & $0+$ & 3.800 & 2.178 & 2.006 \\
\hline $2005-2011$ & IBR & International Business Review & A & 3 & 3 & 1 & 1.489 & 1.375 & 288 \\
\hline $1997-2011$ & JWB & Journal of World Business & A & 3 & 3 & -- & 1.986 & 4.744 & 432 \\
\hline 2007-2011 & JIM & Journal of International Management & $\mathrm{B}$ & 2 & -- & -- & 1.298 & 412 & 142 \\
\hline 1999-2011 & IMR & International Marketing Review & A & 3 & 3 & -- & 2.641 & 2.622 & 493 \\
\hline 1983-2011 & AMR & Academy of Management Review & $\mathrm{A}^{*}$ & 4 & 4 & $0+$ & 6.720 & 112.995 & 1.998 \\
\hline $1958-2011$ & AMJ & Academy of Management Journal & $A^{*}$ & 4 & 4 & $0+$ & 5.250 & 142.467 & 2.902 \\
\hline $1973-2011$ & JBR & Journal of Business Research & A & 3 & 3 & 1 & 1.773 & 27.099 & 2.845 \\
\hline $1983-2011$ & $\mathbf{J} \mathbf{M}$ & Journal of Management & $\mathrm{A}^{*}$ & 4 & 4 & 0 & 3.743 & 47.856 & 1.241 \\
\hline 1966-2011 & JMS & Journal of Management Studies & $A^{*}$ & 4 & 4 & 0 & 3.817 & 30.694 & 2.858 \\
\hline $1992-2011$ & OS & Organization Science & $\mathrm{A}^{*}$ & 3 & 3 & 2 & 2.339 & 48.670 & 941 \\
\hline $1981-2011$ & OSt & Organization Studies & $\mathrm{A}^{*}$ & 3 & 3 & 1 & 0.882 & 22.011 & 2.066 \\
\hline $2008-2011$ & APJM & Asia Pacific Journal of Management & $\mathrm{B}$ & 2 & 3 & 2 & 3.355 & 535 & 113 \\
\hline $1990-2011$ & SMJ & Strategic Management Journal & $\mathrm{A}^{*}$ & 4 & 4 & $0+$ & 3.583 & 120.413 & 1.828 \\
\hline
\end{tabular}

Source: (1) Harzing, A-W. (2011) Journal Quality List, 38 ${ }^{\text {th }}$ edition, Australia. (2) ABDC ranking: Australian Business Deans Council, Journal Rankings, List February 2010 (scale: A*, A, B, C). (3) ABS ranking — Association of Business Schools Academic, Journal Quality Guide, March 2010 (scale: 1, 2, 3, 4, 4*). (4) CRA ranking — Cranfield University School of Management, Journal Rankings, List February 2010 (scale: 1, 2, 3, 4). (5) ESS ranking — ESSEC Business School, Paris 2009/2010 (scale: 0+, 0, 1, 2, 3). (6) Source: <http://admin-apps.webofknowledge.com>. (7) The total number of citations refers to the total citations of articles published in the journal, counted by ISI knowledge. (8) The number of publications includes all types of work published in each journal, from first publication up to 2010. 
The sample was created according to a procedure that identifies and selects all articles that mention at least one of John Dunning's works. This procedure resulted in 697 articles with citations of at least one of Dunning's works. Any differences in the titles of articles, volumes or numbers were corrected and, in the case of books, made uniform with the first edition. We selected these articles and all references in each of the 697 articles for subsequent analysis. Table 4 presents, for each of the 14 journals, the published articles and the total number of articles mentioning Dunning. The growing trend of Dunning citations is evident, even considering the greater number of articles published, revealing increasing acceptance of Dunning's theoretical contribution to the international business discipline. Not surprisingly, the work of Dunning is most mentioned in journals of the discipline - JIBS, $M I R, I B R$, JWB and JIM - and strategy (SMJ, in which 87 published articles mention Dunning).

Table 4 - Articles published, by journal: 1980-2010.

\begin{tabular}{|c|c|c|c|c|c|c|c|c|c|c|c|c|c|c|c|c|c|c|}
\hline Year & $\begin{array}{l}\text { No } \\
\text { (a) }\end{array}$ & JIBS & MIR & IBR & JWB & JIM & IMR & AMR & $\mathrm{AMJ}$ & JBR & JM & JMS & Osc & Ost & APJM & SMJ & Total & $\begin{array}{l}\% \\
\text { (b) }\end{array}$ \\
\hline 2010 & 65 & 81 & 33 & 44 & 42 & 29 & 31 & 27 & 63 & 185 & 56 & 60 & 62 & 71 & 34 & 74 & 892 & 7.3 \\
\hline 2009 & 83 & 77 & 36 & 48 & 39 & 34 & 31 & 32 & 57 & 167 & 55 & 50 & 57 & 62 & 31 & 69 & 845 & 9.8 \\
\hline 2008 & 53 & 75 & 32 & 46 & 33 & 23 & 33 & 43 & 55 & 142 & 40 & 59 & 61 & 53 & 31 & 70 & 796 & 6.7 \\
\hline 2007 & 54 & 66 & & 34 & 34 & 25 & 34 & 55 & 65 & 145 & 37 & 69 & 84 & 58 & & 68 & 774 & 7.0 \\
\hline 2006 & 40 & 52 & & 36 & 29 & & 27 & 49 & 61 & 151 & 38 & 69 & 77 & 48 & & 63 & 700 & 5.7 \\
\hline 2005 & 43 & 40 & & 36 & 29 & & 34 & 37 & 60 & 184 & 44 & 66 & 67 & 44 & & 66 & 707 & 6.1 \\
\hline 2004 & 27 & 31 & & & 30 & & 30 & 29 & 56 & 146 & 43 & 58 & 60 & 48 & & 67 & 598 & 4.5 \\
\hline 2003 & 23 & 41 & & & 27 & & 25 & 34 & 49 & 96 & 43 & 80 & 55 & 45 & & 78 & 573 & 4.0 \\
\hline 2002 & 33 & 43 & & & 27 & & 24 & 26 & 70 & 95 & 36 & 48 & 38 & 43 & & 69 & 519 & 6.4 \\
\hline 2001 & 32 & 46 & & & 22 & & 31 & 27 & 73 & 82 & 33 & 48 & 33 & 43 & & 61 & 499 & 6.4 \\
\hline 2000 & 28 & 41 & & & 23 & & 28 & 46 & 74 & 103 & 49 & 49 & 42 & 43 & & 69 & 567 & 4.9 \\
\hline 1999 & 19 & 41 & & & 25 & & 25 & 43 & 44 & 73 & 36 & 44 & 37 & 43 & & 63 & 474 & 4.0 \\
\hline 1998 & 27 & 40 & & & 24 & & & 37 & 44 & 67 & 32 & 38 & 40 & 53 & & 65 & 440 & 6.1 \\
\hline 1997 & 23 & 31 & & & 22 & & & 27 & 54 & 66 & 31 & 35 & 36 & 40 & & 65 & 407 & 5.7 \\
\hline 1996 & 17 & 43 & & & & & & 40 & 64 & 70 & 36 & 35 & 41 & 40 & & 67 & 436 & 3.9 \\
\hline 1995 & 16 & 37 & & & & & & 31 & 54 & 65 & 54 & 36 & 36 & 42 & & 43 & 398 & 4.0 \\
\hline 1994 & 12 & 32 & & & & & & 24 & 41 & 72 & 38 & 34 & 34 & 39 & & 51 & 365 & 3.3 \\
\hline 1993 & 11 & 34 & & & & & & 23 & 38 & 39 & 40 & 40 & 30 & 32 & & 52 & 328 & 3.4 \\
\hline 1992 & 14 & 30 & & & & & & 26 & 26 & 41 & 37 & 37 & 25 & 28 & & 55 & 305 & 4.6 \\
\hline 1991 & 16 & 32 & & & & & & 31 & 26 & 53 & 36 & 33 & 24 & & & 52 & 287 & 5.6 \\
\hline 1990 & 18 & 29 & 32 & & & & & 31 & 34 & 52 & 42 & 31 & 23 & & & 45 & 319 & 5.6 \\
\hline 1989 & 6 & 25 & 25 & & & & & 26 & 31 & 40 & 38 & 32 & 26 & & & 43 & 286 & 2.1 \\
\hline 1988 & 11 & 19 & 28 & & & & & 28 & 28 & 52 & 38 & 32 & 31 & & & 53 & 309 & 3.6 \\
\hline 1987 & 4 & 16 & 27 & & & & & 48 & 29 & 41 & 48 & 32 & 15 & & & 36 & 292 & 1.4 \\
\hline 1986 & 6 & 31 & 27 & & & & & 49 & 30 & 41 & 40 & 33 & 17 & & & 32 & 300 & 2.0 \\
\hline 1985 & 4 & 22 & 29 & & & & & 64 & 39 & 41 & 27 & 31 & 16 & & & 20 & 289 & 1.4 \\
\hline 1984 & 5 & 38 & 27 & & & & & 62 & 43 & 35 & 18 & 22 & 14 & & & 24 & 283 & 1.8 \\
\hline 1983 & 2 & 28 & 28 & & & & & 63 & 42 & 35 & 16 & 23 & 16 & & & 24 & 275 & 0.7 \\
\hline 1982 & & 26 & 29 & & & & & & 52 & 36 & & 21 & 14 & & & 24 & 202 & 0.0 \\
\hline 1981 & 3 & 27 & 34 & & & & & & 47 & 27 & & 19 & 17 & & & 24 & 195 & 1.5 \\
\hline 1980 & 2 & 23 & 46 & & & & & & 38 & 33 & & 21 & & & & 24 & 185 & 1.1 \\
\hline Total (c) & & 1,197 & 433 & 244 & 406 & 111 & 353 & 1,058 & 1,487 & 2,475 & 1,081 & 1,285 & 1,128 & 875 & 96 & 1,616 & 13,845 & 5.0 \\
\hline Total (d) & & 281 & 43 & 77 & 45 & 24 & 9 & 14 & 27 & 24 & 15 & 24 & 11 & 13 & 3 & 87 & 697 & \\
\hline
\end{tabular}

Source: data collected by the authors.

Note: (a) Total number of articles that mention Dunning's work, per year. (b) \% of articles published in the journal, over the period, mentioning Dunning's work. (c) Number of articles published in each journal in the 1980-2010 period. (d) Number of articles that mention Dunning, by journal. 
Data collected was organized using the Bibexcel software - available on http://www.umu. se/inforsk/Bibexcel - for generating citation and co-citation matrixes, according to the method proposed by Ramos-Rodriguez and Ruiz-Navarro (2004).

\section{RESULTS}

Figure 1 shows an increasing trend in the use of Dunning's work in International Business research, from initial work in the early 1980s on. Although other conceptual perspectives have emerged in research carried out in the discipline, perhaps specially the Resource-Based View in the 1990s, or approaches based on institutional theory, Dunning's Eclectic paradigm has maintained and enhanced its relevance. In 2009, around $10 \%$ of the articles published in the 14 chosen journals mentioned at least one of Dunning's works.

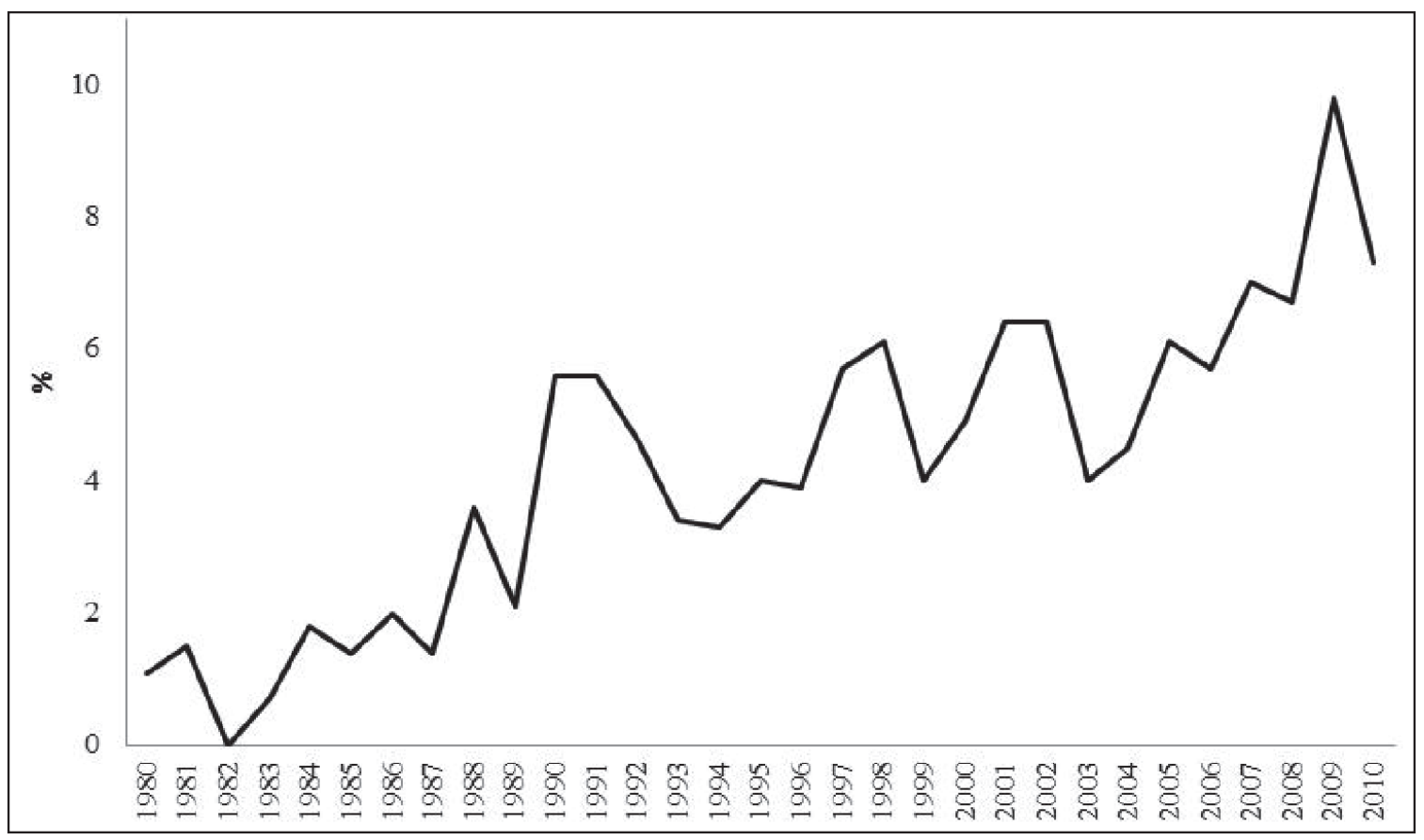

Figure 1 - Evolution of Dunning citations: 1980-2010 (\%)

Source: research data collected in the ISI web of knowledge.

Note: data in percentage of total (see \% column in Table 4).

Table 5 presents the 12 most mentioned works in the sample, with special mention of the 1993 book Multinational Enterprises and the Global Economy as the most mentioned. 
Table 5 - Most mentioned Dunning articles.

\begin{tabular}{|c|c|}
\hline Articles & $\begin{array}{l}\text { Number of } \\
\text { citations }\end{array}$ \\
\hline DUNNING, J. (1993a) Multinational Enterprises and the Global Economy. (Book) & 236 \\
\hline $\begin{array}{l}\text { DUNNING, J. (1988) The Eclectic Paradigm of International Production: a Restatement and some Possible } \\
\text { Extensions. (Article) }\end{array}$ & 141 \\
\hline $\begin{array}{l}\text { DUNNING, J. (1980) Toward an Eclectic Theory of International Production: Some Empirical Tests. } \\
\text { (Article) }\end{array}$ & 112 \\
\hline $\begin{array}{l}\text { DUNNING, J. (1977) Trade, Location of EconomicAactivity and the MNE: a Search for an Eclectic } \\
\text { Approach. (Book chapter) }\end{array}$ & 96 \\
\hline DUNNING, J. (1981b) International Production and the Multinational Enterprise. (Book) & 91 \\
\hline DUNNING, J. (1998) Location and the Multinational Enterprise: a Neglected Factor. (Article) & 80 \\
\hline DUNNING, J. (1995) Reappraising the Eclectic Paradigm in the Age of Alliance Capitalism. (Article) & 64 \\
\hline DUNNING, J. (1988) Explaining International Production. (Book) & 57 \\
\hline $\begin{array}{l}\text { DUNNING, J. (1979) Explaining Changing Patterns of International Production: in Defense of the } \\
\text { Eclectic Theory. (Article) }\end{array}$ & 38 \\
\hline DUNNING, J. (1973) The Determinants of International Production. (Article) & 34 \\
\hline $\begin{array}{l}\text { DUNNING, J. e RUGMAN, A. (1985) The Influence of Hymer's Dissertation on the Theory of Foreign } \\
\text { Direct Investment. (Article) }\end{array}$ & 34 \\
\hline $\begin{array}{l}\text { DUNNING, J. (2000) The Eclectic Paradigm as an Envelope for Economic and Business Theories of } \\
\text { MNE Activity. (Article) }\end{array}$ & 34 \\
\hline
\end{tabular}

Source: data collected from ISI Web of knowledge, authors' calculations.

Figure 2 presents a map of co-citations for the 20 most mentioned authors, alongside Dunning's works. The figure reveals three different effects: first, the connections between different works (an article or book by a given author); second, the strength of the existing link; and third, the position of relative centrality or periphery. Dunning's 1993 article appears in the center of the figure, as the most mentioned - the closer the articles are to the center, the greater the number of co-citations. For example, Dunning (1993a), Johanson and Vahle (1977) and Buckley and Casson (1976) are more central and closer, indicating that they present the most co-citations and that, given their centrality, are more relevant to all other works. From Dunning (1993a) on, important connections to the work of Kogut and
Zander (1993) and Kogut and Singh (1988) are established, in 53 connections, and also to Caves (1982), in 63 connections. The connections between Dunning's 1977 and 1980 articles and Buckley and Casson's book (1976) on the future of multinational enterprises must also be mentioned, because multinational enterprises exist when companies invest and expand in foreign markets.

Analysis of Figure 2 also reveals the relative centrality of each work (article or book) to other works. In the vicinity of Figure 2 are the works that, although they present a great number of co-citations with Dunning, are still less relevant to other works in the network. This is the case, for example, of Porter (1990), which, although important, is less relevant to the remaining 18 works in the network. 


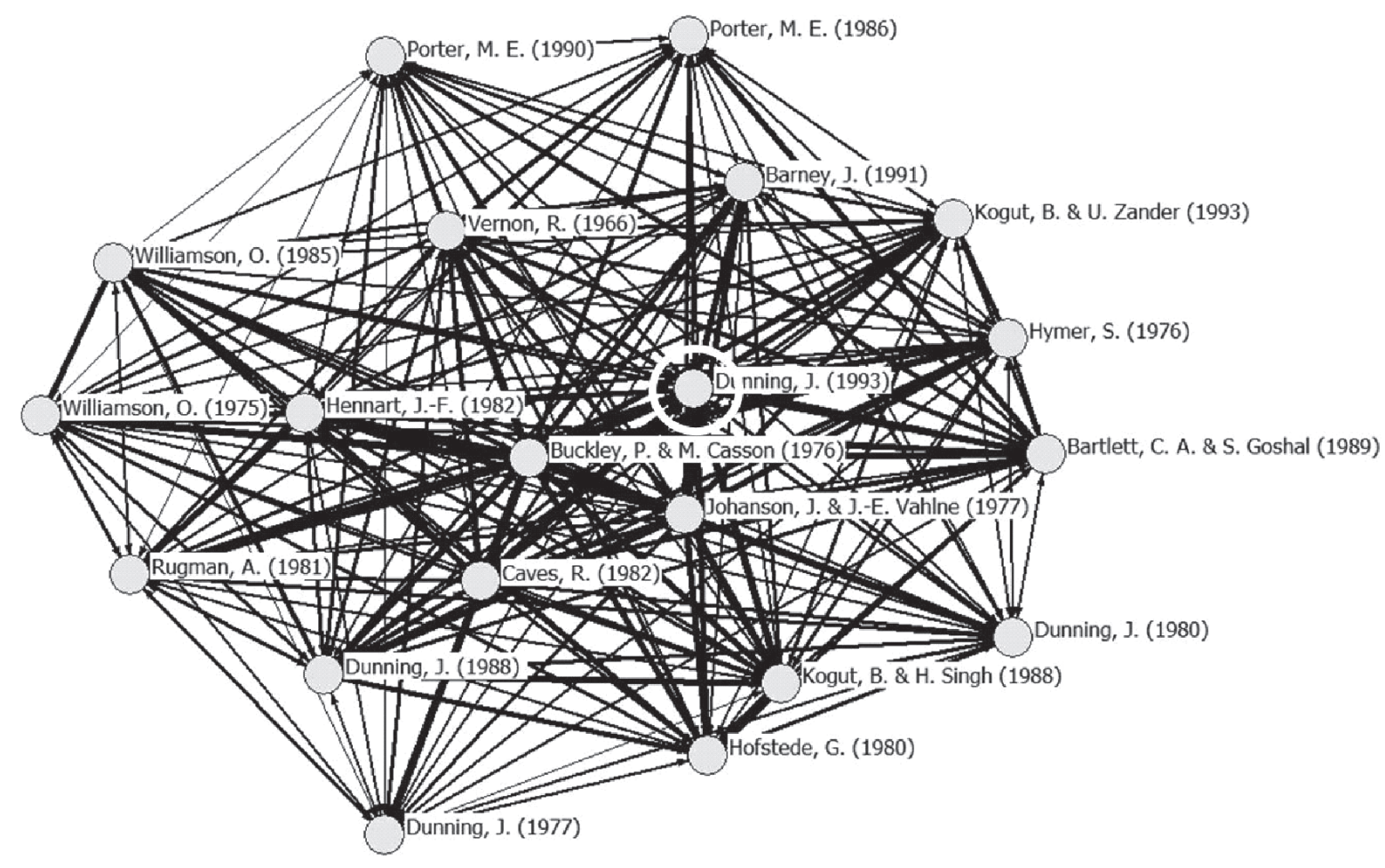

Figure 2-Map of 20 most mentioned articles' co-citations.

Source: Research data with authors' calculations. Figure created by Ucinet software.

Note: Network of connections between 20 works with the most co-citations with Dunning.

The relative thickness of lines reflects the intensity of the link between each work, and is a measure of the frequency of citations. The software moves to the edge of the figure works which, although they present many co-citations with Dunning, are less frequently mentioned in other works. Therefore, the position in the network and the strength of the link reveal the relative use of a given work in existing research.

It is interesting to understand which of the researched topics use Dunning's work. Bibliometric analysis carried out does not allow for analysis of the individual content of each of the 697 articles mentioning Dunning. This analysis is carried out in a direct and possibly more significant way by analysis of keywords provided by the authors. Please note that authors suggest a set of keywords in their articles to express their content, or for cataloging purposes, either by journals or in libraries, or to identify potential topics to interested readers. Thus, it is reasonable to state that keywords given by authors allow for reasonable identification of topics covered by their articles.

Figure 3 presents the 697 selected articles's main keywords (altogether, these articles used 1082 different keywords). Please note that the main topics of the articles mentioning Dunning refer to foreign direct investment (FDI) and multinational enterprises (MNE), to all extents the core of Dunning's contribution. Other issues - such as knowledge, globalization, emerging economies and markets, location, disadvantages of being foreign, entry modes and internationalization - are also significant. Globally considered, these are the main topics of research in international business. Analysis carried out is prima facie evidence that Dunning's work contributes to the research of the discipline's main topics. 


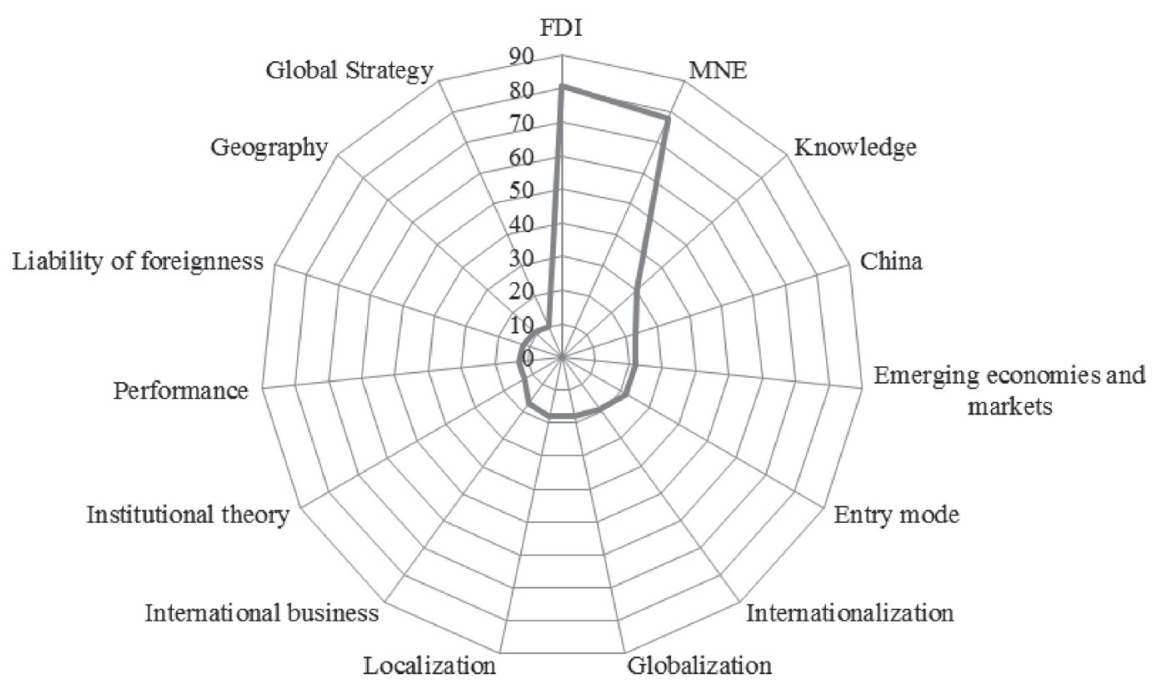

Figure 3 - Main topics in articles that mention Dunning.

Source: Research data, authors' calculations.

Note: Topics identified in the figure represent almost $40 \%$ of all articles' topics (or keywords).

\section{DISCUSSION}

In this article, we examine the influence of the work of teacher and researcher John Dunning on Management research and, specifically, on the International Business discipline over the last three decades. Dunning's legacy is recognized for its conceptual contribution to the evolution of the discipline, and its taxonomy OLI is widely used in research. Theoretical analysis of Dunning's work, in the first part of this article, was followed by a bibliometric study in 14 of the main Management journals that publish research on international business. Following bibliometric study procedures, this work involved the analysis of nearly 22,000 published articles, which, altogether, have been mentioned over 604,000 times. As a sample for empirical analysis, we created a database that included 697 articles published from 1980 to 2010 in the 14 listed journals, mentioning at least one of Dunning's works. With this study, we sought to realize the impact of an author and of his proposals - especially of the Eclectic paradigm - as well as the intellectual structure of connections with other authors and theories or topics. Analysis of citations and co-citations and a brief look at topics allowed us to identify how Dunning's work is employed.
Bibliometric study allows us to observe a set of results. First, we noticed how Dunning's work and his eclectic paradigm play an increasingly important role in International Business research and discipline (Figure 1). Analysis in Figure 2 allowed us to identify connections between Dunning's work and a group of authors and theories. The figure reveals several topics and currents of thought in international business. For example, the connection with Johanson and Vahlne (1977) reveal that there is great proximity between the OLI taxonomy and work on internationalization as a gradual and incremental process, as proposed by the Swedish school of Uppsala. Even in gradual internationalization, companies makes use of their competitive advantages and sequentially choose locations for their productive investments.

The co-citation of Dunning with Michael Porter, specially in 1990 and 1986 articles, reveals proximity with topics such as location advantages and the need to explore and learn about foreign markets where MNEs internationalize, but also facing competition in global industries. There is also proximity to work on transaction costs (WILLIAMSON, 1975, 1985; RUGMAN, 1981; HENNART, 1982) - the decision to internalize operations abroad requires assessment 
of internalization advantages that can be withstood in comparison to the transaction costs of different alternatives, or entry modes. Buckley and Casson (1976), for example, focus on the existence of multinational enterprises as a way of overcoming the imperfections of the intermediate goods market, primarily of knowledge. Co-citation with the work of Vernon (1966), about products' international life cycle, is explained by an attempt to understand the flows of trade and investment and, possibly, complementary in deciding which are the best locations for operating with direct investment.

Please note the connection between Dunning and a theoretical approach that is increasingly important in international business - the resource-based view. One of the most notorious articles is Barney's (1991), which identifies and explains the four characteristics that strategic resources should have in order to give the enterprise a competitive advantage. In the same line of thought is the work of Kogut and Zander (1993) about knowledge and an evolutionary perspective of multinational enterprises. The connection between these works may be in ownership advantages, as proposed by Dunning, and in enterprises' need to have competitive advantages as essential conditions to internationalization.

Culture is one of the most commonly use dimensions in international business research (Ferreira et al., 2009). We must mention the co-citation with the work of Hofstede (1980), who defines four cultural dimensions, and with the article of Kogut and Singh (1988) which presents the cultural distance concept and the effect of national culture on choosing an entry mode. Cultural differences lead to uncertainty in international operations and in entry into foreign markets. Uncertainty affects not only the choice of a location, but also leads enterprises to choosing an entry mode (hence, to the decision to internalize) that minimizes risks. As a way of reducing risks, one possible solution is to enter first markets that are closer and less different, learning from these operations before venturing to markets that are more distant and different (JOHANSON; VAHLNE, 1977).

This work has limitations that must be mentioned, specially regarding the empirical component. These are, for example, the limitations of the bibliometric method itself and of the use of only 14 journals when carrying out analysis. Journals were chosen because they are available for consultation, but there are other magazines that also include research in international business. On the other hand, certain journals do not possess their whole publishing history available in the ISI Web of Knowledge. Still, journals chosen are amongst the most prestigious in Management and that publish international business academic articles. Limitation is, therefore, in generalizing results, given that only a small part of all published research in Management was used.

Another limitation, also inherent to the bibliometric method, is the difficulty to observe the context in which citations are made. In some cases, authors mention previous work to support a given argument; in others, they use citations to reveal contrast or even to criticize. The bibliometric method used does not infer the context in which a citation is made, but future research can overcome this limitation with more extensive content analysis (RAMOSRODRIGUEZ, RUIZ-NAVARRO, 2004). In this study, content, or topic, is observed only through the frequency of keywords (Figure 3). Indeed, it is reasonable to suggest that the analysis of keywords is a more demanding test than alternative techniques, but does not provide further detail. Future research, however, can deepen understanding of topics dealt with by the use of content analysis methodologies, eventually using specific software or creating taxonomies of research topics and areas and rating contributions and applications in each of the articles.

Finally, we must note that older books and articles usually present the greatest number of citations. This is an observation rather than a limitation of this study. The truth is that older works are better known, and that some reach a status of "classics", making their citation in new research "mandatory". 
Future research may evolve in various directions. For example, using a broader base of scientific journals, and perhaps separating academic journals from other journals geared towards managers (such as the Harvard Business Review). It would also be interesting to analyze the interrelationships between authors - and their theories or conceptual proposals - through statistical methods that allow for creating more elaborate networks and clusters of articles and theories. These analyses can be relevant to better understand which authors and theories are more central to research and those which are more peripheral. Similarly, future research may include a longitudinal component, observing that authors and theories disappear or emerge as the most mentioned in certain periods and how these variations over time reflect external concerns and events.

\section{FINAL OBSERVATIONS}

Dunning's work is based on OLI taxonomy, which presents three conditions for companies to carry out productive investment abroad. These conditions embody three kinds of advantages ownership, location and internalization - which must occur simultaneously for the company to internationalize through international production abroad, instead of using alternatives like exporting or licensing. That is, not all internationalization movements are relevant, only those meaning foreign investment, but they imply the need for companies to consider, since the beginning, what are the specific advantages they possess (or ownership advantages) that can allow them to compete successfully in foreign markets. Next, it must assess location advantages that countries offer and where the implementation of direct investment is really the best option compared to alternatives such as licensing or export.

In conclusion, it is important for scholars to understand the impact of selected authors, authors whose contributions mark, or marked, the evolution of the discipline, as well as understand how this impact occurs. Part of this understanding is in the analysis of the structure of knowledge and of interrelationships between theories, concepts, authors and schools of thought. The life and work of Dunning, through his work, are striking in the study of international business, and his contributions impact business decisions. Dunning's contribution, apparent in the Eclectic paradigm, systematized three conditions that govern the internationalization of companies and extends to forms or models of internationalization, to the ways in which companies organize themselves internally to transact in markets and to the very choice of destinations. Nowadays, for managers and scholars, the work of Dunning is a crucial reference for research and practice.

\section{REFERENCES}

AKERLOF, G. A. The market for 'lemons': quality uncertainty and the market mechanism. Quarterly Journal of Economics, Cambridge, v. 84, n. 3, p. 488-500, Aug. 1970.

ALCHIAN, A. A.; DEMSETZ, H. Production, information costs, and economic organization. American Economic Review, Nashville, v. 62, n. 5, p. 777-795, Dec. 1972.

BARNEY, J. Strategic factor markets: expectations, luck and business strategy. Management Science, Hanover, v. 32, n. 10, p. 1231-1241, Oct. 1986.

Firm resources and sustained competitive advantage. Journal of Management, Thousand Oaks, v. 17, n. 1, p. 99-120, Mar. 1991.

BARTLETT, C. A.; GHOSHAL, B. S. Managing across borders: the transnational solution. Boston: Harvard Business School Press, 1989.

BUCKLEY, P. J.; CASSON, M. The future of the multinational enterprise. London: Macmillan, 1976.

CAVES, R. E. Multinational enterprise and economic analysis. Cambridge: The Cambridge University Press, 1982. 
DUNNING, J. H. Alliance capitalism and global business. London: Routledge, 1997.

American investment in British manufacturing industry. London: Allen \& Unwin, 1958.

. The determinants of international production. Oxford Economic Papers, Oxford, v. 25, n. 3, p. 289-336, Nov. 1973.

The eclectic paradigm as an envelope for economic and business theories of MNE activity. International Business Review, London, v. 9, n. 2, p. 163-190, Apr. 2000.

The eclectic paradigm of international production: a restatement and some possible extensions. Journal of International Business Studies, Basingstoke, v. 19, n. 1, p. 1-31, Spring 1988.

An evolving paradigm of the economic determinants of international business activity. In: CHENG, J. ; HITT, M. (Ed.). Managing multinationals in a knowledge economy: economics, culture, and human resources. Amsterdam: Elsevier, 2004. v. 15, p. 3-27.

Explaining changing patterns of international production: In defense of the eclectic theory, Oxford Bulletin of Economics and Statistics, Oxford, v. 41, n. 4, p. 269-295, Nov. 1979.

Explaining the international direct investment position of countries: towards a dynamic or developmental approach, Weltwirtschaftliches Archiv, Kiel, v. 117, p. 30-64, 1981a.

Globalization and the theory of MNE activity. In: HOOD, N.; Young, S. (Ed.). The globalization of multinational enterprise activity. Londres: Macmillan, 1999a. v. 2, p. $1-54$.

The globalization of business. London: Routledge, 1993b.
International production and the multinational enterprise. Londres: Allen \& Unwin, 1981b.

Location and the multinational enterprise: a neglected factor. Journal of International Business Studies, Basingstoke, v. 29, n. 1, p. 4566, 1st Qtr. 1998.

The location of international firms in an enlarged EEC: an exploratory paper. Manchester: Manchester Statistical Society, 1972.

Multinational enterprises and the global economy. Wokingham: Addison-Wesley, 1993a.

Reappraising the eclectic paradigm in the age of alliance capitalism. Journal of International Business Studies, Basingstoke, v.26, n. 3, p. 461-491, 3rd Qtr.1995.

A Rose by any other name...? FDI theory in retrospect and prospect. Mimeo: University of Reading and Rutgers University, 1999b.

. Toward an eclectic theory of international production: Some empirical tests. Journal of International Business Studies, Basingstoke, v. 11, n. 1, p. 9-31, Spring-Summer 1980.

Trade, location of economic activity and the MNE: a search for an eclectic approach. In: OHLIN, B.; HESSELBORN, P.; WIJKMAN, P. (Ed.) The international allocation of economic activity: proceedings of a Nobel symposium held at Stockholm. London: Macmillan, 1977. p. 395-418.

DUNNING, J. H.; LUNDAN, S. M. Multinational enterprises and the global economy. 2nd ed. Basingstoke: Edward Elgar, 2008.

DUNNING, J.; RUGMAN, A. M. The influence of Hymer's dissertation on the theory of foreign direct investment. American Economic Review, Nashville, v. 75, n. 2, p. 228-232, May 1985. 
DUNNING, J.; WYMBS, C. The challenge of electronic markets for international business theory. International Journal of the Economics of Business, London, v. 8, n. 2, p. 273-301, July 2001.

FERREIRA, M. P. A bibliometric study on Ghoshal's managing across borders. Multinational Business Review, St. Louis, v. 19, n. 4, p. $357-$ 375, 2011.

FERREIRA, M. P. et al. Is the international business environment the actual context for international business research?. Revista de Administração Empresas, São Paulo, v. 49, n. 3, p. 282-294, jul./set. 2009.

FERREIRA, M. P. et al. John Dunning's influence in IB/ strategy research: a bibliometric study in the SMJ. Journal of Strategic Management Education, Dublin, v. 7, n. 2, 2011.

GUISINGER, S. From OLI to OLMA: incorporating higher levels of environmental and structural complexity into the eclectic paradigm.

International Journal of the Economics of Business, London, v. 8, n. 2, p. 257-272, 2001.

HEDLUND, G. The hypermodern MNE: a heterarchy?. Human Resources Management, Oxford, v. 25, n. 1, p. 9-35, Spring 1986.

HARZING, A-W. Journal quality list 2011. Available at: http://www.harzing.com

HENNART, J.-F. A theory of multinational enterprise. University of Michigan Press: Ann Arbor, 1982.

HOFSTEDE, G. Culture's consequences: international differences in work related values. Beverly Hills: Sage Publications, 1980.

HUGGINS, R.; DEMIRBAG, M.; RATCHEVA, V. I. Global knowledge and R\&D foreign direct investment flows: recent patterns in Asia Pacific, Europe, and North America. International Review of Applied Economics, Abingdon, v. 21, n. 3, p. 437-451, 2007.
HYMER, S. H. The international operations of national firms: a study of FDI. Cambridge: MIT Press, 1976.

JOHANSON, J.; VAHLNE, J. The internationalisation process of the firm: A model of knowledge development and increasing foreign market commitment. Journal of International Business Studies, Basingstoke, v. 8, n. 1, p. 2332, Spring/Summer 1977.

KOGUT, B.; CHANG, S. J. Technological capabilities and Japanese foreign direct investment in the United States. Review of Economics and Statistics, Cambridge, v. 73, n. 3, p. 401-413, Aug. 1991.

KOGUT, B.; SINGH, H. The effect of national culture on the choice of entry mode. Journal of International Business Studies, Basingstoke, v. 19, n.3, p. 411-432, Autumn 1988.

KOGUT, B.; ZANDER, U. Knowledge of the firm and the evolutionary theory of the multinational corporation. Journal of International Business Studies, Basingstoke, v. 24, n. 4, p. 625-645, Dec. 1993.

Knowledge of the firm, combinative capabilities, and the replication of technology. Organization Science, Linthicum, v. 3, n.3, p. 383-397, Aug. 1992.

LAHIRI, S.; KUMAR, V. Ranking international business institutions and faculty members using research publication as the measure: update and extension of prior research. Management International Review, Wiesbaden, v. 52, n. 3, p. 317-340, June 2012.

LEONTIEF, W. Domestic production and foreign trade: the American capital position re-examined. Proceedings of the American Philosophical Society, Philadelphia, v. 97, n. 4, p. 332-349, Sep. 1953.

LI, D.; FERREIRA, M.P.; SERRA, F. R. Technology transfer within MNEs: intersubsidiary competition and cooperation. Revista 
de Administração e Inovaçáo, São Paulo, v. 6, n.1, p. 139-158, 2009.

LU, J. W. The evolving contributions in international strategic management research. Journal of International Management, New York, v. 9, n. 2, p. 193-213, 2003.

MCCAIN, K. W. Mapping authors in intellectual space: a technical overview. Journal of the American Society for Information Science, New York, 41, n. 6, p. 433-443, Sep. 1990.

Nelson, R. R.; Winter, S. G. An evolutionary theory of economic change. Cambridge, Mass: Harvard University Press, 1982.

NORTH, D. C. Transaction costs, institutions and economic history. Zeitschrift fur die Gesamte Staatswissenschaft (JITE), Tuebingen, v. 140, n. 1, p. 7-17, Mar. 1984.

PENG, M. W.; ZHOU, J. Q. Most cited articles and authors in global strategy research. Journal of International Management, New York, v. 12, n. 4, p. 490-508, Dec. 2006.

PENROSE, E. The theory of the growth of the firm. New York: Oxford University Press, 1959.

PETERAF, M. A. The cornerstones of competitive advantage: a resource-based view. Strategic Management Journal, Chichester, v. 14, n. 3, p. 179-191, Mar. 1993.

PISANI, N. International management research: investigating its recent diffusion in top management journals. Journal of Management, Thousand Oaks, v. 35, n. 2, p. 199-218, Mar. 2009.

PORTER, M. E. The competitive advantage of nations. New York: Free Press, 1990.

POSNER, M. V. International trade and technical change. Oxford Economic Papers, Oxford, v. 13, n. 3, p. 323-341, Oct. 1961.

RAMOS-RODRIGUEZ, A. R.; RUIZNAVARRO, J. Changes in the intellectual structure of strategic management research: a bibliometric study of the Strategic Management Journal, 1980- 2000. Strategic Management Journal, Chichester, v. 25, n. 10, p. 981-1004, Oct. 2004.

RUGMAN, A. M. Inside the multinationals: the economics of internal markets. London: Croom Helm, 1981.

SPENCE, A. Informational aspects of market structure: an introduction. Quarterly Journal of Economics, Cambridge, v. 90, n. 4, p. 591-597, Nov. 1976.

STOIAN, C. R.; FILIPPAIOS, F. Dunning's eclectic paradigm: a holistic, yet context specific framework for analysing the determinants of outward FDI: evidence from international Greek investments. International Business Review, London, v. 17, n. 3, p. 349-367, June 2008.

TAHAI, A.; MEYER, M. J. A revealed preference study of management journals' direct influences. Strategic Management Journal, Chichester, v. 20, n. 3, p. 279-296, Mar. 1999.

TALLMAN, S. B. Strategic management models and resource-based strategies among MNEs in a host market. Strategic Management Journal, Chichester, v. 12 , n. 1 p. 69-82, 1991. Special Issue.

TEECE, D. J. The multinational enterprise: market failure and market power considerations. Sloan Management Review, Cambridge, v. 22, n. 3, p. 3-17, Spring 1981.

. Transaction cost economics and the multinational enterprise: an assessment. Journal of Economic Behavior and Organization, Amsterdam, v. 7, n. 1, p. 21-45, Mar. 1986.

TREVINO, L. J. et al. A perspective on the state of the field: international business publications in the elite journals as a measure of institutional and faculty productivity. International Business Review, London, v. 19, n. 4, p. 378-387, Aug. 2010 . 
VERNON, R. International investments and international trade in the product cycle. Quarterly Journal of Economics, Cambridge, v. 80, n. 2, p. 190-207, May 1966.

WERNER, S. Recent developments in international management research: a review of 20 top management journals. Journal of Management, Thousand Oaks, v. 28, n. 3, p. 277-305, June 2002.

WERNERFELT, B. A resourced-based view of the firm. Strategic Management Journal, Chichester, v. 5, n. 2, p. 171-180, Apr./June 1984.

WHITE, H. D.; MCCAIN, K. W. Visualizing a discipline: an author co-citation analysis of information science, 1972-1995. Journal of the American Society for Information Science, New York, v. 49, n. 4, p. 327-355, 1998.
White, H. D.; GRIffiTH, B. C. Author co-citation: a literature measure of intellectual structure. Journal of the American Society for Information Science, New York, v. 32, n. 3, p. 163-171, May 1981.

WILLIAMSON, O. E. The vertical integration of production: market failure considerations. American Economic Review, Nashville, v. 61, n.2, p. 112-123, May 1971.

Markets and hierarchies: analysis and antitrust implications. New York: Free Press, 1975.

\section{The economic institutions of}

capitalism: firms, markets, relational contracting. New York: The Free Press, 1985. 